\title{
Data provenance, metadata, and reflexivity: Comments on method
}

\author{
Procedencia de la información, metadatos y \\ reflexividad: Comentarios sobre el método
}

\section{La Provenance des données (ou de l'information), les métadonnées et la réflexivité : Commentaires sur la méthode}

\author{
Bruce Curtis \\ Carleton University, Canada
}

\begin{abstract}
Researchers faced with large, routinely-generated record systems may think themselves compelled to choose between accepting their empirical materials as given in order to pursue research questions, or closely examining the provenance of their materials. I argue that researchers can employ a reflexive historical method that allows us to both address research questions with evidence, as well as to examine how the provenance of our sources shapes our research practice.
\end{abstract}

Key words: archives, provenance, metadata, reflexivity, historical method.

\section{RESUMEN}

Los investigadores que se enfrentan con grandes sistemas de registro y generados rutinariamente pueden sentirse obligados a elegir entre aceptar su material empírico como dado con el fin de proseguir con las preguntas de investigación o examinar detenidamente la procedencia de sus materiales. Considero que los investigadores puede emplear una método histórico que nos permita tanto abordar las cuestiones de investigación partiendo de la evidencia como examinar cómo la procedencia de nuestras fuentes moldea nuestra práctica de investigación.

Descriptores: archivos, procedencia, metadatos, reflexividad, método histórico.

RÉSUMÉ

Les chercheurs confrontés à de vastes systèmes d'archives recueillies systématiquement peuvent 
se croire obligés de choisir entre accepter leurs matériaux empiriques tels que donnés afin de poursuivre leurs questions de recherche, ou de vérifier attentivement la provenance de leurs matériaux. Je soutiens que les chercheurs peuvent employer une méthode historique réflexive qui permet de confronter les questions de recherche avec l'évidence et d'examiner comment la provenance de nos sources forme la pratique de notre recherche.

Mots clés: archives, provenance, métadonnées, réflexivité, méthode historique.

A S WITH OTHER STATE BUREAUCRACIES, public educational systems keep records in an official documentary system. Even very small bureaucracies can generate staggeringly large quantities of such materials. Researchers in educational history, as in other fields, often have to engage with such massive data sets, many parts of which are routinely-generated. We need practical, workaday tactics and strategies for dealing with them, and we need to locate these strategies in larger theoretical considerations. In this intentionally eclectic article, I engage with two overlapping matters: data provenance and metadata, and reflexivity in research methods.

I draw my empirical examples mainly from 19th century Canadian state papers, particularly those produced by the Education Office in Canada West (Ontario) and by the Department of Agriculture and Statistics, which organized the population census. In 1860, the central Education Office staff consisted of a chief and deputy superintendent, two clerks, a salesman for the book depository, an accountant, and a messenger. The office received and responded in some way to several hundred letters a month for over 3,000 elementary schools in 1850, and up to a thousand letters a month for over 5,000 schools in the 1870 s. Correspondence came from teachers, trustees, the friends and family members of students, from community members, and from the Office's own small cadre of school superintendents. Almost every item of incoming correspondence was preserved, and the Office also maintained a record of its outgoing responses. Before the typewriter made the work easier, copies were blotted onto onion-skin flimsies and bound in correspondence books. The Office's 19th century incoming correspondence alone amounts to some hundreds of linear feet of letters in the Public Archives of Ontario. ${ }^{1}$

Correspondence files for the Education Office are a major, but by no means the only, part of its official documentary system. They were augmented by reports from officials at all levels of the bureaucracy and the chief superintendent's reports to the legislature. There were financial accounts and audits, teacher superannuation records, a monthly official Journal of Education, records of county boards of public instruction, legal decisions, copies of reports on educational conditions in other jurisdictions in a large departmental library, architectural drawings for schools, Normal and Model School attendance registers, examination results, and a mass of other material.

\section{Provenance and metadata}

It might seem self-evident that researchers must approach the materials they use as data and evidence with a clear understanding of who produced such materials, for which purposes, under which conditions, and using which means: the matter of data 
provenance. Yet any researcher facing a large, routinely-generated set of records faces what Alain Desrosières called the "metadata paradox." Desrosières was not thinking about what are called 'metadata' in current debates over security and privacy; those data consist of the whole range of every-person identifiers generated by digital technologies. Rather, in his usage, metadata are data about data. The paradox is caused by an apparent opposition between investigating the provenance of a data set, or using the data set confidently to address research questions. All researchers have a normative obligation to reveal the provenance of the data they use, but as Desrosières suggests, some researchers seeking to use routinely-generated databases "do not want to (or cannot) know what happened before the data entered the base. They want to be able to trust the 'source' (here the database) as blindly as possible to make their arguments - backed by that source - as convincing as possible" (p. 346). For researchers who adopt such an attitude "the data set is a black box... The user's trust in the data-production phase is a precondition for the social efficiency of the statistical argument" (p. 349). ${ }^{2}$

Desrosières was writing especially about statistical analysis, but all researchers face some version of this dilemma. ${ }^{3}$ Users of statistical data sets operate at a greater remove from first-order observations than do researchers not using numerical data. The numbers used by the former are abstracted from first-order observations and these are themselves the outcomes of 'infrastructural work': all the practices that are necessary before an imagined research project can issue in a final research report (Bowker, 1994; Bowker \& Star, 1999; Hansen, Monteiro, \& Hatling, 1996; Poovey, 1998; Scott, 1998).

The education archive contains statements and claims made at varying distances from first-order observations. Furthest removed are such things as annual reports to the legislature on the state of the system. ${ }^{4}$ These reports typically include material in prose, as well as such things as statistical accounts of student numbers, attendance rates, staffing, expenditures, and so on, and these are materials that have been abstracted from the lower-level system reports of a variety of observers. Attendance rates, for instance, were typically compiled from reports delivered by county boards of education and school superintendents, reports that were based in turn on teachers' and inspector's reports of inscriptions in school-level attendance registers. As such, the rates involve abstractions from reports of reports, and any thorough account of their provenance would involve the reconstruction of the decision-making processes guiding the initial determination of who was in attendance at school. Being in attendance' was itself a judgment made using more or less conventional criteria such as 'was in the schoolroom' - for some greater or lesser part of the hours of instruction. At times, however, educational discourse distinguished 'mere presence' from 'productive attendance': physical presence from attention and receptivity to instruction. The former was easier to standardize numerically than the latter. ${ }^{5}$ Tracing the conditions under which any of the successive judgments in this chain were made might be a research project in itself - hence an education researcher interested in school attendance would confront a variety of the metadata paradox.

Yet we must appreciate that the substance of a concept such as 'attendance at 
school' configures the object of study in specific ways. Physical presence points to the role of the schooling project in organizing population segments in time and space. 'Productive attendance' further distinguishes the population in question in terms of subjective engagement in schooling, and hence underpins a notion of and a project for subjectification.

Collections of correspondence are much closer to first-order observations than are statistical accounts, and so the work of provenance is rather different than for those who work with reports and abstracts. Questions of provenance involve such matters as who is writing, in what manner, on what occasions, for what discernable purposes, and in what context. The substantial bulk of correspondence might tempt researchers to adopt the sampling strategies employed by producers of statistical data sets. Faced with the Education Office's endless shelves of archived letters, and limited research time, one might decide to sample the data set more or less randomly, more or less purposively, in an effort to understand its essential elements.

Such a strategy would 'black-box' the data set and would assume that letters were somehow sufficiently uniform that a sample of them could represent the whole in a useful way. For some questions, that might be the case. Letters were almost always signed. With a minimum of interpretation, a researcher could sample the correspondence to measure such characteristics of writers as their gender, their degree of comfort with the pen, and perhaps their ethnic background. Inconclusive in itself, charting such regularities could provide research directions - perhaps more or fewer women wrote as time went on? - and evidence for argumentation.

However, correspondence files do not lend themselves well to sampling techniques because of their structure as a set of data. Consider Eric Sager's (1998) forceful argument in favour of the large-scale sampling of case files. Sager studied an archive of employment contracts between workers and owners in maritime shipping, contracts kept in very large numbers on standard forms. He had a sophisticated analysis of the provenance of such forms, including the power relations between workers and owners that shaped their content. Reading across the contracts revealed regularities at the heart of such power relations, and Sager criticized the tendency of some researchers to practice 'instancing': choosing cases from a data set that supported argumentation without considering how representative such instances were of the data set as a whole. Large-scale sampling was a necessary corrective to such inadequate attention to provenance.

Sager did not 'black box' the data, but his example is a data set that is flat and uniform. Each contract can be treated as an entity in its own right, and because contracts are standardized, each contract is the equivalent of any other: they constitute a 'population.' For other sets of data, his method and his cautions about instancing do not apply in the same way. The Canada West correspondence is neither flat nor uniform, even if education bureaucrats sought to make it so. The correspondence consists of exchanges: enquiries, responses, attempts to contest responses, efforts to enforce responses, and so on. Its individual items are linked in complex ways. Selective sampling cannot capture the structure of the data set, nor can large-scale observation of the sort proposed by Sager. Since the data set is not flat and uniform, 
careful 'instancing' after reading some larger or smaller set of the correspondence is a necessary research strategy.

The point is perhaps more forcefully made when considering legal case files. Such files may be uniform in the sense of their form and mode of presentation, but in any legal or bureaucratic system that is based on precedent, precedent-setting instances are clearly different from instances where precedents are applied. Not adopting a strategy of selective instancing in such a circumstance would be an inadequate research strategy. On the other hand, only to study precedent-setting cases would be to risk overlooking the routine or mundane work of legal administration against the background of which precedents emerge. It would also be to risk ignoring the logic that determines what is and what is not precedent-setting. ${ }^{6}$

I suggest that the metadata paradox is not a paradox but a set of opportunities for the multiplication of research questions, for a more penetrating engagement with data, and hence for the broadening and deepening of our contributions to knowledge. Researchers do not need to choose between provenance and use. We can investigate the ways in which provenance can shape usage. Provenance includes the ways in which documentary systems are implicated in attempts to order and organize parts of the world within their purview. If we face numerical data, we can ask how they were derived and we can use them to make arguments; at the same time, we can be cognizant that a different derivation of the data would produce different evidence. This position has been elaborated at more length by practitioners of 'reflexive' sociology and 'reflexive' historical sociology.

\section{Reflexivity}

'Reflexivity' is a social science buzzword that has been taken to mean a great many different things in different fields by different scholars. ${ }^{7}$ I use it here in the senses proposed by Pierre Bourdieu and Arpad Szakolczai. Both authors reject the divide between the subjects and the objects of science, and both elaborate research methods that are quite comprehensive. Researchers can select some of these methods without being compelled to adopt all of them.

Rejecting the subject/object divide means accepting that the subjectivity of the researcher is an indissoluble element in the research process. Reflexive sociological method does not shrink from the challenge posed to the human sciences by the fact that the research process and its objects are part of the constitutive experience of the investigator. Reflexive sociology rejects the maneuver of most empiricism, which pretends that the subjectivity of the researcher can be neutralized in the research process through the adoption of technical methods. Such methods themselves are products of specific kinds of human activity, vary in use, and shape the objects of research in specific ways.

John Law and John Urry provide a useful overview of the position I have just enunciated. They point out that social science does not simply describe a world; rather, its practice actively shapes its world. It configures the object of investigation and it can create new phenomena that have real effects and consequences. If we configure worlds, suggest Law and Urry, we are engaged in "ontological politics." 
Their claim is that researchers need to assume the responsibilities that come with configuring the world in particular ways. Left-leaning historical sociologists of my generation, for instance, learned the painful lesson that our configurations of welfare institutions, including public education, as mechanisms of class domination were correct, but limited, and were easily appropriated by the neo-liberal attack on the welfare state. Critics of authoritarian schooling sought a 'relevant' education: neoliberals treated 'relevance' to be satisfaction of the demands of employers (Law \& Urry, 2004). ${ }^{8}$

The researcher's 'horizon of interpretation' will have consequences for the research object. ${ }^{9}$ Pierre Bourdieu (2001b) argued in consequence that reflexive researchers need "to exercise a specific form of epistemological vigilance" (p. 173): to be attentive to and to be cognizant of the ways in which the practices, procedures, and projects of knowledge-production have a formative influence on objects of knowledge - and on the politics in which they are embedded. ${ }^{10}$ Part of this vigilance involves self-reflection as cultivated and critical attention both to one's relation to the field of research and its objects, and to the operative sets of categories and concepts one mobilizes in the research effort. In his characteristically circular mode of expression, Bourdieu argued that we successfully grasp objects of research only when we can objectivate the subject of research. For the researcher, biography and autobiography are key to adequate understanding of research practice (Bourdieu, 2001b, p. 73).

Yet both Bourdieu and Szakolczai are concerned to avoid "narcissistic reflexivity" -that obnoxious confessional practice which demands that the researcher own up to their position of privilege before presuming to investigate anything. At its most deformed, this stance holds that only the dominated are capable of understanding their domination, and all attempts by outsiders to understand domination only reinforce it. Bourdieu insisted, correctly, that such a stance claimed privileged (rather than particular) access to knowledge while neglecting or denying the damage that domination does to the dominated. It supposes that perfect self-knowledge is possible, in which case there would be no domination and no point in social scientific research. There is always more going on than people know is going on (Bourdieu, 2001a, pp. 114-116)..$^{11}$

Narcissistic reflexive practices are also obnoxious because they may deflect researchers from epistemological vigilance. Such vigilance is an active and ongoing research practice; it is not exhausted by some sort of declaration, which would leave one free to go about one's business unimpeded. Narcissism is comparable to the strategy present in much writing in the field of history and history of education in which authors open their work with a declaration of critical theoretical loyalties and then proceed to accept in an unreflecting manner the concepts and categories present in their empirical corpus.

Reflexive research practice strives continually to maintain the double awareness of the historicity of its empirical corpus and of its own specific historical and political relation to that corpus. This is a craft skill that requires agility. Researchers must be critically self-aware, but, as Szakolczai (1998b) stresses, we also need a historical anthropology of selfhood in order to avoid narcissism. As he put it, "there is nothing 
subjective about the history of subjectivity" (p. 217). Moreover, as Bourdieu (2001b) claimed, there exists "an intelligible statistical relationship between the scientific strategies of different scholars and their characteristic social origins, their trajectories, and so on" (p. 86). Our disciplinary 'eyes' and 'tastes' are products of our own social formation, of the conditions of practice in the fields to which we gravitate, and of the questions or problems in those fields which attract us. Again, these are not research weaknesses, but ways of deepening understanding and knowledge.

I will not follow further here the ambitious programs of reflexivity elaborated by these two authors. Readers may find it rewarding to engage with Bourdieu's attempts to analyse the research strategies likely to be adopted by scholars with particular habituses in given research fields at particular moments in the development of both individual career and research field. ${ }^{12}$ At least as rewarding for me are Szakolczai's arguments that a reflexive historical sociology has as its most general objects forms of knowledge and thought, forms of subjectivity, and the variable discipline of temporal and spatial relations. His reading of the work of social theorists as biography, liminality, and formative 'reading experiences' is equally significant (Szakolczai, 1998a, $2000 \mathrm{a}, 2000 \mathrm{~b})$. Thinking about one's own formative 'reading experiences' and their consequences is an important part of reflexivity. I will write briefly about some of my practical engagements with the archive.

\section{In the archive}

In a first engagement with archival materials, I spent twelve months in 1983-4 working through the Canada West Education Office archive. I read all of the incoming and outgoing correspondence for the period from 1842, when the Office's records began, through to the end of 1871 , when there was a major reorganization of the educational system. I read a good many additional office records and publications. Access was free of charge and the luxury and desperation of a post-doctoral fellowship meant that I read everything in the correspondence files. With no computer, I made notes by hand on file cards - which forces one to be selective and efficient. The work was demanding and it was filthy, since the correspondence had been stored for a considerable part of its life near the coal furnace in the basement of the Normal School in Toronto. By the time I had worked to the mid-1860s, I had acquired an archives cough and wore a respirator as a defense against black lung. ${ }^{13}$

But I also acquired what Arlette Farge (1989) christened "a taste for the archive." Part of this "taste" has to do with the orderly routine of the work and its comforting familiarity. I lived a short bicycle ride away from the archive and could pop in for a few hours on weekends or evenings. Like a great many other researchers - from Farge herself to Karl Marx in the British Library - I had a favourite seat and was offended if some interloper was in it when I arrived. One gets to know the staff and there is an agreeable sense of recognition that one is more serious than the great majority of casual archives visitors. Many archivists, particularly subject specialists, enjoy sharing parts of record collections that are not commonly used and one might get behind the scenes to see rare originals or uncatalogued material. Starting out is always daunting, because one does not know what there is to find and often doesn't find what one 
expects, but soon the pleasures of collecting take over and there is the satisfaction that comes from piling up files and notes. Historical actors become familiar. Patterns and networks emerge. On their heels, with luck and application, comes the vibrant and energizing pleasure of discovering things - things one did not know and then perhaps things that no one knows.

At the same time, because of my own formation, I felt as if I was rifling through the files in my own high school's main office. Getting behind the scenes of an institution I had experienced as mostly offensive, monolithic, and impermeable, and watching the powerful scheme and plot, meet and work to contain opposition, were exciting and fascinating. My own ancestors even appeared now and then: a letter from a distant cousin who was a municipal councilor in 1847; my maternal grandmother's Model School examination records from 1903.

My engagement was influenced by my own reading experiences that included the revisionist trend in North American educational historiography, a theoretical framework on state formation shaped by cultural varieties of Marxism, by the work of Michel Foucault and Norbert Elias, and by a biography that included experience of the 1950s-60s public schools of a small Ontario city. ${ }^{14}$ Together, the three influences made me skeptical both of the cozy 'little red schoolhouse' stories that dominated pre-revisionist historiography, and of the social control analysis that underpinned early critical revisionist work. The first two influences framed the public educational project as one of state formation. I understood state formation to be indissolubly both the organization and discipline of population, and the formation of 'character,' selves - political subjectivities, and hence public education.

I understood power relations to be 'positive' in the Foucauldian sense - forces that create new energies, that incite, that work through a dynamic of fear and pleasure, that seek to anchor rule and government in the self, to 'encourage' subjects to embrace the conditions of rule. In the discourse of educational reform, educators frequently wrote of 'free and cheerful obedience.' They scorned simple obedience, to which social control analysis limited itself, but valued obedience that resulted from the colonization of the will. Educators would write that it was not enough to make schoolchildren behave correctly when they were being watched at school; they needed to learn that 'the angels are always watching,' hence to watch themselves. Emile Durkheim framed such self-scrutiny as "moral regulation" (Durkheim, 1961[1925]).

The theoretical influences resonated with my own experience in myriad ways and shaped what I saw in the archive. I had a few good teachers and I was fortunate to attend elementary school before the invention of Ritalin. One good teacher taught me high school French and German - a petite woman in her fifties who ruled by terrorizing and selectively humiliating her students, but who forced me to work and let me discover I could do languages: violence and pleasure. Another when I was 16 was an English teacher, mild-mannered and tweedy, offering students an unusual degree of liberty, who drove a sports car and dated the school's hottest female teacher. His permissive style allowed me to experiment with writing, but such permissiveness in an authoritarian atmosphere made it hard for him to manage his classes, which I noticed. I enjoyed winning the high school Geography prize. But I was also exposed to 
a number of thugs, mostly men, mainly ex-army officers in the technical courses that boys of my generation were forced to follow, but also a math teacher whose regularly staged outbursts of volcanic temper were half-terrifying, half-absurd.

We students were not passive recipients of power relations nor heroes of own lives. Although I was mild-mannered, students were generally alert to any opening to challenge or to subvert teachers, often in ways I found cruel at the time. My first Chemistry teacher was a young woman in her first year of teaching, whose lisp was parodied so rudely and openly whenever her back was turned that she was frequently reduced to tears, forced to call in the vice-principal in charge of 'discipline' to maintain order, and eventually quit mid-term. The volcanic math teacher pulled down his graph chart with his back to it in class one day to discover, through a chorus of mad chortling, that someone had taped the centerfold from a Playboy magazine to it. His rage was impotent and, while he tried collective punishment to discover the culprit, no one would own up. A woodworking teacher I had was beaten up by his older students in a storage room, and left teaching for the Christian ministry. I was interested by such dynamics of schoolroom government, and I saw them and others played out in the archival record.

I was also subjected to administrative decisions, which were usually mysterious and unpleasant, but consequential and intriguing. As I was a speedy class clown, smart but without application to schoolwork, my school had trouble placing me. I was accelerated through grades four and five in a single year, which was disorienting, and I hung out with the older, tough boys, who were generally anti-school but they were going through puberty, aged 13-14 when I was 10-11, and I didn't fit. Plus I was an avid reader, although not for much of what was assigned in school. My well-to-do elementary school had a small working class population and students were split into sections in grade 7 . Although the school was formally democratic, the classes were streamed, with section 7D composed of the 'tough' and 'dumb' kids, mainly working class young people. I ended up in it, for reasons I still don't get, and unlike some other students whose parents protested against the placement of their kids - since only a few students could study both music (Band) and French seriously, and 7D got a few minutes of French a week - my parents did not intervene. I found the atmosphere exotic - I was 12-13 and there was one student who was 19, several others over 16, they drank and had sex - but it was also leadenly boring. I acquired a postural slump and I was beaten once after the deadening misery of being incarcerated in a brainless class led me to explode in insolence.

In secondary school, $80 \%$ of which was tedium, I read a lot of literature and some philosophy, while also living what Wilhelm Reich called "the sexual misery of youth.” My university-educated older siblings fed me things - Peter Berger's Invitation to Sociology was one when I was 15. And as a 16 and 17-year-old, I consumed quite a bit of existentialism, especially Sartre's trilogy starting with Iron in the Soul, and Camus' The Fall. Reading Sartre is not particularly healthy recreation for a miserable teenager. I read more or less serious fiction for fun: Michener, Maugham, H.G. Wells, Graham Greene, and all of Steinbeck, for instance. And I encountered odd things that influenced me seriously, too; a pop psychology book by Eric Berne called 
Games People Play really made me start looking at my experience of social relations and other people's activities as objects that were orderly and that could be analysed. Bourdieu's work is game-theoretic.

As a university undergraduate in the period in which Frankfurt School critique, Marxist humanism and political economy, and anti-psychiatry combined with new social movements, psychedelic drugs, and the sexual revolution, I was receptive to critical sociology, to capital-critique, as well as to the phenomenological 'micro'-sociologies. Goffman's 1961 essay “The Underlife of a Public Institution" and his analysis of 'total institutions' were primers for a later engagement with Foucault's analysis of discipline, and with Foucault's attention to what he called "subjugated knowledges." Thinking about the latter is a way to come to grips with what we know experientially as subjects of institutional treatment, in contrast to the institution's accounts of itself.

\section{Reading strategies}

I read the archive with the formation I have described and more that I haven't, and I read it as a weird object, trying to understand its form and organization in addition to its contents. I heard the voices of educational reformers, but I was especially attentive to the voices of those recalcitrant to discipline and to the educational project's underlife. Methodologically, to contrast claims about the nature and means of some social project with its empirical substance is standard critical sociology. But working to situate the archive in the wider span of Canadian educational history provided insight into some of the events in my own school life - for instance, the reorganization of the Ontario high school system in the wake of Sputnik explained why I was compelled to take a four-part series of 'shop' classes in grade 9, which I had expected would not be obligatory in secondary school. Once again, such an insight is a standard element in the sociological imagination - C.W. Mills' (1959) insistence that personal troubles are public issues.

The Canada West education collection is exceptionally diverse. There are thousands of voices, a great many of them untutored, which offer unexpected windows into the interactions of official with local and popular cultures. Reflexivity encourages us to hear the turns of phrase and the varieties of conceptual language that present themselves in the several discourses involved in this correspondence: that of correspondents, and that of officials, against the backdrop of our own conceptual repertoire. Reflexivity also encourages us to think about the difference in social relations and practices involved in operating within different conceptual universes.

The project for public instruction was explicitly meant to 'improve' local culture and practice by changing people's capacities, habits, understandings, and tastes: it was a disciplinary project that sought to create new forms of subjectivity - new ways of being and living - which are not innocent. Educational officials attempted to place the population to be disciplined in official categories. The people targeted in this way sometimes embraced such categories willingly, sometimes demanded them, but at other times rejected them or tried to substitute alternative categories and practices.

The project sought to create a new social classification, 'school age population,' composed of 'schoolchildren' and 'pupils' under the domestic control of authoritative 
'parents.' As Alison Prentice pointed out, before the public educational project, young people in rural agricultural communities and neighbourhoods who went to school were known simply as 'scholars': people attending school. Below the petty bourgeoisie, they tended not to have authoritative, biological 'parents,' but to exist in networks of 'friends' and 'relations.' In many communities, young people and other resources circulated among households. Young people worked in house, yard, and field as soon as they were able and throughout the nineteenth century, agricultural households depended on their labour (Prentice, 1975). Turning 'scholars' into 'schoolchildren' and attributing authority over them to 'parents' was a conflict-laden process. It changed authority relations in local communities and infantilized young people. As it worked, it removed their autonomy and liberty in a variety of ways, while opening up other ontological possibilities for them.

A reflexive approach to this phenomenon demands that one learn to hear such conceptual and linguistic shifts and that one be alert to the changes in social relations and political structures that underpin them. One might wholeheartedly endorse the public educational project and accept on some grounds that it was worthwhile or necessary, but one would be remiss in not noticing that there was a reconstruction of the form and substance of social life at work there. And one would be remiss in not rethinking one's own experience of the successfully established categories in light of the evidence of difference (that is, historical anthropology).

In the archive, routinely-generated historical records are 'messy.' They contain inconsistencies and anomalies. Bureaucrats dealing with correspondence typically must organize, categorize, and classify materials they receive, and they do so more or less consistently and coherently. They have to engage in coding activities - to make practical decisions about the substance and importance of the materials they encounter - and, as a large body of sociological literature has shown, they will apply the official categories they are meant to employ by using common sense methods of comparison and similitude (Bowker \& Star, 1999; Donnelly, 1997; Douglas \& Hull, 1992; Garfinkel, 1968; Lynch, 1991).

As researchers, we need to sustain our capacity for surprise and see the essential weirdness of the taken for granted. A simple injunction for archival researchers is to take careful note of anything that seems odd - one rarely gets to reread the material - and to wonder why it strikes one as odd. Insights frequently lurk here. Reflexivity seizes on difficulties in coding and classification. Oddities, things that 'don't fit' (I didn't fit well in the schools), point to the substance and perhaps the political force of systems of classification. For example, Bowker and Star show that lack of fit can 'torque' people's biographies in unexpected ways. Lorna Weir has examined the clash between official medical classifications around pregnancy and birth and the classifications employed by midwives; the two frame the object of classification in incompatible ways, so that what fits for midwives doesn't fit for some officials, and pregnant women may be pulled in different directions (Bowker \& Star, 1999; Weir, 2006).

Things that don't fit are often relegated to the margins of official documentary systems, or they are passed over in silence. They may present themselves to us literally as marginalia - writings in the margins of official documents. Those engaged in projects 
of public management may try to expurgate them, or to create conditions which will prevent them from being registered in the first place. The manager of the 1871 Canadian census, for instance, explicitly enjoined enumerators not to add marginalia to their census schedules and tried to design schedules on which there was little space for enumerators to write in any case. Yet it was in their marginal comments that they described how they went about their work and the problems they encountered with the enumeration grid. Such accounts are a key part of data provenance, while bringing the margins back to the center is a key practice of reflexive historical sociology. That practice demands the exercise of another craft skill - the capacity to hear what is not said in what is said, and to attend to what did not happen but could have. ${ }^{15}$

At the same time, as records for which bureaucrats and politicians may be called to account, official documentary systems are susceptible to various kinds of manipulation. Researchers must be attentive to this kind of work as well. It means reading past and through documents, as official representations, to the realities they shape and may attempt to disguise. Elsewhere I have shown how mid-19th century Canadian government ministers dealt with a socially obnoxious political ally whom they felt obliged to employ but who was a pariah to all office managers. The employee had to figure in the public accounts, but had no firm attachment to any public office, and so floated from one place to another in the official accounts. He did not fit in any department and sometimes secretaries or deputy-ministers protested loudly when their superiors tried to fit him into in the official accounts of their departments. Following his case reveals things about patronage politics as well as about how official documents sought to regularize an anomaly (Curtis, 1993a).

Quite early on, the Education Office tried to make correspondents fit their letters into a standard format, to shape how and about what correspondents would write. Similar steps were taken to organize and classify material so that it could be dealt with efficiently. Correspondents were instructed to write only about a single subject and to identify that subject clearly at the outset of their letters. While the office had initially kept letters loose, early in the 1850 s clerks folded each letter into a numbered, narrow rectangle of heavy blue paper and noted on the outside the date and origin of the letter, its author and subject matter, and the location of any response. Placed in open-ended files in chronological order, the letters were kept in a manner meant to ensure easy reference.

Of course, correspondents were unruly, preoccupied with their own concerns and not first with those of the Education Office, and the degree of comfort with the pen they evinced varied a great deal. Clerks had to order and organize their messy communications so as to fit them into the official documentary system, and in doing so they made choices and decisions. Reflexivity intervenes for the researcher here at several points, but given that the raw material of the original letters and the outcome of the work of classification are both available to us, it is possible to reconstruct some of the practices that translated messy correspondence into things to be acted upon by officials.

Or, indeed, not to be acted on. By the early 1860s, a very large portion - perhaps the majority - of letters reaching the office concerned mundane issues of curriculum, 
textbooks, and the workings and price policies of the Educational Depository. Clerks would routinely classify letters as concerned with textbooks. After many hundred instances in which letters classified as textbook letters turned out to be textbook letters, I was tempted not to perform the tedious and dusty operation of unfolding the letter cover, but to accept the clerk's description of the items and to move on to the next item in the series in the quest for something more interesting.

But since the official demand was that writers write about one subject only, and given that clerks placed the subject matter of each letter into one category only, letters that covered more than one subject could easily be treated officially as dealing with only the subject which the clerk found relevant. The correspondence on textbooks and curriculum contained a growing volume of letters from the early 1860s in which correspondents denounced the official curriculum based on the Irish National Reading books. Yet, occasionally, a letter denouncing textbooks would contain something else, as well - a complaint of a male teacher groping the older female students was one example. The regulation of sexual conduct at school was generally cloaked in official silence in this period; no curriculum material dealt with it directly, and higher level officials were notoriously reticent to comment on such matters. Classification work underpinned the official silence and correspondents who wanted attention paid to such things usually had to insist (Curtis, 1989).

The normalization of any administrative organization is evident when its system of classification and coding has become stable. Periods in which activists or officials have yet to routinize such things are particularly informative for reflexive method. The absence of stable coding should not be seen as an imperfection or a failure. To do so would be to accept some idealized situation as a measure of practice, while tracing out the course of routinization and stabilization provides us deeper insight into the operation of administration. In the earliest educational inspections, for instance, inspectors made judgments about what they observed and categorized what they saw in seemingly idiosyncratic ways using standards that were implicit - although these bear the marks of their own horizons of interpretation. Their rudimentary and primitive accumulations of intelligence and their judgments in the Canadian case were reported to the Education Office which, in turn, worked to standardize them and to remove the visible marks of character of the observer from them. Here, we can see the translation of class- and gender-bound perceptions into the seemingly neutral garb of bureaucratic assessment (Curtis, 1993b).

For examining the work of amateur observers attempting to follow a coding scheme, Canada's archive of 19th century manuscript census schedules is both extremely rare and particularly instructive. In 1861, for instance, hundreds of census enumerators, a large majority of whom in Canada West were farmers with more or less polished literary aptitudes, were dispatched in the middle of a Canadian winter to produce a mass of information about social conditions and relations. In this case, their census schedules had been designed by a former county superintendent of education, who had hoped to use school sections as census districts and school teachers as enumerators. Neither project worked, since school sections were often ill-defined and could not be used to catch everyone, and they were usually so small that the pay for 
making the census was too low to attract teachers to do the work. Nonetheless, even the failed attempt shows one way in which the educational project was implicated in wider processes of state formation.

The enumerators were given no training and very little written guidance as to how to make coding and classification decisions. Because the census agency had not done necessary infrastructural work, informants were often incapable of answering census queries. The enumeration was a novelty for those being enumerated; one enumerator commented that many of his potential informants were not, in his phrase, "comeatable." He meant that it was impossible simply to present himself in front of people who didn't know him personally and have them agree to answer questions. That situation speaks to the novelty of a politics of knowledge which we take as given (Library and Archives Canada, 1861b). ${ }^{16}$

We can see enumerators using their own common sense and their standards of propriety to make what they perceived on the ground fit the categories on the census schedules. The 'occupations' category was particularly troublesome, in part because enumerators received the rather stupid instruction to accord an occupation to everyone and to give sons the occupations of fathers - so, some two-year-old boys were reported as exercising crafts. Some enumerators ignored the instruction, and some used the 'custom of the country' to record young people as workers only from eight or ten years of age.

In this patriarchal society, attributions of occupations to women were a source of inconsistency, with many enumerators confusing social status and work roles. We can read of women described as 'spinster,' 'wife,' 'lady,' 'servant,' 'seamstress,' 'none,' 'housekeeper,' 'adopted,' 'squaw' (on the reserve at St. Regis), 'labourer,' and 'widow farming,' among many others. In French-speaking areas of Quebec, where French civil law prevailed, many enumerators refused to accord women any productive occupation. Other enumerators explicitly refused to record women as engaged in agricultural labour, thinking field work unfitting for them. And there were many instances where enumerators had trouble deciding what to say about people; Elenor Morrison's marginal Kitley Township household was one. She was recorded as living with her three daughters aged 21, 11, and 9, for whom no occupation was given. Her two sons aged 16 and 13 were both recorded as 'labourer.' Morrison was described as married and not widowed, although there was no husband listed. The enumerator gave her occupation as 'Private' (Library and Archives Canada, 1861a). ${ }^{17}$ What did he mean? That we shouldn't ask what she did for a living? That it was none of our business? That she did something illicit?

Higher up the observational chain, these descriptions were reworked and re-coded using official categories that somehow managed to collapse diverse and ambiguous descriptions into apparently consistent ones. That work is important in itself. Reflexive historical method draws our attention to the fact that, just as 'scholars' became 'schoolchildren' through a structural reorganization of relations of power and authority, so people became occupied workers only with the development of a fully developed capitalist labour market, in which everyone of age would have an occupation or be 'unemployed.' 


\section{Conclusion}

Coding difficulties are not usefully seen as 'errors' unless one takes for granted a classification scheme. To do the latter would be to suppress our capacity for surprise and to neglect our ontological-political responsibilities. Focusing on coding difficulties what doesn't fit - forms part of the 'epistemological vigilance' required of the reflexive researcher. At the same time, doing so multiplies our possible engagements with the material we use; we can see at once the processes of fabrication of elements of social order, and we can probe the consequences of particular ways of fabricating such order. Educational historiography is a privileged site for reflexive historical work. Every one of its practitioners has been 'educated,' and a great many of us spend our lives educating others. The unity of research subject and research object should be especially evident to us, and with it comes the obligation to practice a critical self-awareness in research practice. On the other hand, rejecting the pretense of a division between research subject and object opens up new avenues for knowledge production.

\section{Notes}

1. I first encountered the archive after reading work by Gidney, Lawr, and Millar. From a larger set of contributions, see for instance Gidney, R. D. (1972). Centralization and education: The origins of an Ontario tradition. Journal of Canadian Studies, 7, 33-48; Gidney, R. D, \& Lawr, D. A. (1980). Bureaucracy vs community? The origins of bureaucratic procedure in the Upper Canadian school system. Journal of Social History, 13, 438-457; Gidney, R. D, \& Lawr, D. A. (1980). Who ran the schools? Local influence on education and education policy in nineteenth century Ontario. Ontario History, 72, 131-143; Gidney, R. D., \& Millar, W. P. J. (1985). From voluntaryism to state schooling: The creation of the public school system in Ontario. Canadian Historical Review, 66, 443-473.

2. As the title suggests, there are four different attitudes to such data one might adopt. I am describing only one of the four; the one I suggest below is a fifth.

3. Social theorists face a 'metatheory' paradox: they may think themselves forced to choose between investigating the fundamental assumptions, the conditions of elaboration, or the political thrust of a theory, or of taking such things as given in order to use it to address a research question.

4. For an examination of strategies of data presentation - textual economies see Curtis, B. (2006). Textual economies and the presentation of statistical material: Charts, tables and texts in 19th century public education. Scientia Canadensis, 30, 3-29.

5. For an analysis of how, practically, to come to grips with reports of attendance, see Gidney, R. D., \& Millar, W. P. J. (2012). How schools worked: Public education in English Canada, 1900-1940. Montreal and Kingston, Canada: McGill-Queen's University Press.

6. In the same collection to which Sager contributed, the point is carried by 
James W. St. G. Walker in "A Case for Morality: The Quong Wing Files” (On the Case, pp. 204-223). Walker discusses a legal case that set the racist precedent, sustained by the Supreme Court of Canada, that Chinese restaurateurs could be debarred from employing 'white' women on the grounds of the moral protection of the latter. I am speaking to an old debate in social science history and in empiricist versions of social science, which I will not pursue here. Historical sociologists are often anxious about claims that their findings are not representative of some larger phenomenon and hence are not 'scientific.' But representativeness of findings in the empiricist sense is predicated upon having a population as a data set, and most of the time we do not.

7. See Caron, C. (2013). Reflexivity at work: Making sense of Mannheim's, Garfinkel's, Gouldner's and Bourdieu's sociology (Unpublished Ph.D. dissertation). Carleton University, Ottawa. Caron did a sociometric analysis of the word, showing the dramatic increase in its use in the social sciences, especially after 1980.

8. The creation of 'public opinion' by the social sciences is discussed in Osborne, T., \& Rose, N. (1999). Do the social sciences create phenomena? The example of public opinion research. British Journal of Sociology, 50, 367-396. The role of the social sciences in creating people who understand themselves and others in terms of 'selfesteem' is examined in Ward, S. (1996). Filling the world with self-esteem: A social history of truth-making. Canadian Journal of Sociology, 21, 1-23. For a critique of reproduction theory in education with specific reference to Bourdieu and Passeron's work, see: Rancière, J. (2005 [1992]). On the shores of politics. (L. Heron, Trans.). London, England: Verso, 2005. Sociologists of education can see an inverted form of the consequences of critique in Diane Ravitch's shift from conservativism to liberal reform in her educational commentary.

9. Hans-Georg Gadamer (1989) develops the concept in Truth and Method (2nd ed.). New York, NY: Continuum Publishing.

10. "Il ne s'agit pas de poursuivre une nouvelle forme de savoir absolut mais d'exercer une forme spécifique de la vigilance épistémologique..."

11. For a useful account on standpoint, see Smart, C. (2009). Shifting horizons: Reflections on qualitative methods. Feminist Theory, 10, 295-308.

12. It is striking how Bourdieu attempts to read his own research biography using his method, and how he commits a version of the 'scholastic fallacy' he commonly denounces by limiting the influences on his trajectory to the scholarly. See Bourdieu, P. (2004). Esquisse pour une auto-analyse. Paris, France: Raisons d'agir.

13. Not as dangerous an occupation as early library and archive workers, who might contract anthrax from working with sheepskin parchment. See Steedman, C. (2002). Dust: The archive and cultural history. New Brunswick, NJ: Rutgers University Press. My first major report on the research was published as Curtis, B. (1988). Building the educational state: Canada West, 1836-1871. London, Ontario, and Sussex, England: Althouse Press and Falmer Press.

14. And, of course, influenced by much else besides, which would be tedious to recount - but my father was teaching elementary school at age 17 in 1923, subsequently attended Ottawa Normal School and worked to reclaim the young people of several Ontario villages from ignorance, indolence, dissipation and sloth, before 
getting a university degree and teaching university. His background shaped my experience of elementary schooling in many ways: my strict grade 5 teacher had been at normal school with him, and in his mind, in principle the school was always right - which I found difficult, since often it was not right for me.

15. See Foucault, M. (1980 [1976]). Two lectures. In C. Gordon (Ed.), Power/ knowledge: Selected interviews and other writings, $1972-1977$ (pp. 78-108). New York, NY: Pantheon. For reading weirdness, see Foucault, M. (2011). Le beau danger. Entretien avec Claude Bonnefoy. Paris, France: Éditions EHESS, pp. 59-64.

16. Remarks on p. 2 of Agricultural returns: "The inhabitants in my section are generally comfortably off particularly where system and energy go hand in hand. On the contrary, I have seen some poverty, nay misery (or at least it would be misery to me) it is easily accounted for by an observant eye. Ignorance in the first place, then a lack of energy or determination to do better. It is a lamentable fact that I have come across some large families where all are ignorant as regards education and but few of these attending school. People will not if they can possibly avoid it tax themselves to educate the rising generation. This is to be deplored... I encountered some considerable difficulty in getting the above [agricultural information], often not finding the man or head of the family at home, and very many of them when comeatable, did not know how to answer my questions with regard to acres of different crops, value of stock... so that the task of the Enumerator was tedious with many."

17. On censuses, see Curtis, B. (2006). The politics of demography. In R. E. Goodwin \& C. Tilly (Eds.), The Oxford handbook of contextual political analysis (pp. 1066-1090). Oxford, England: Oxford University Press; Curtis, B. (2001). The politics of population: Statistics, state formation, and the Census of Canada, 1840-1875. Toronto, Canada: University of Toronto Press.

\section{References}

Bourdieu, P. (2001a). Masculine domination. (R. Nice, Trans.). Stanford, CT: Stanford University Press.

Bourdieu, P. (2001b). Science de la science et réflexivité: Cours du Collège de France, 2000-2001. Paris, France: Éditions Raisons d'Agir.

Bowker, G. (1994). Science on the run: Information management and industrial geophysics at Schlumberger, 1920-1940. Cambridge, MA: MIT Press.

Bowker, G., \& Star, S. L. (1999). Sorting things out: Classification and its consequences. Cambridge, MA: MIT Press.

Curtis, B. (1989). 'Illicit' sexuality and public education in Ontario, 1840-1907. Historical Studies in Education/Revue d'histoire de l'éducation, 1, 73-94.

Curtis, B. (1993a). Comment dénombrer les serviteurs de l'État au Canada-Uni: Essai méthodologique. Revue d'bistoire de l'Amérique française, 46, 607-628. http://dx.doi. org/10.7202/305147ar

Curtis, B. (1993b). Mapping the social: Jacob Keefer's educational tour, 1845. Journal of 
Canadian Studies, 28, 51-68.

Desrosières, A. (2001). How real are statistics? Four possible attitudes. Social Research, 68, 339-355.

Donnelly, M. (1997). Statistical classifications and the salience of social class. In J. R. Hall (Ed.), Reworking class (pp. 107-131). Ithaca, NY: Cornell University Press.

Douglas, M., \& Hull, D. (Eds.). (1992). How classification works: Nelson Goodman among the social sciences. Edinburgh, Scotland: Edinburgh University Press.

Durkheim, E. (1961 [1925]). Moral education. New York, NY: Free Press.

Farge, A. (1989). Le goût de l'archive. Paris: Seuil.

Garfinkel, H. (1968). Common sense knowledge of social structures: The documentary method of interpretation in lay and professional fact finding. In H. Garfinkel (Ed.), Studies in ethnomethodology (pp. 76-103). Englewood Cliffs, NJ: Prentice-Hall.

Goffman, E. (1961). Asylums: Essays on the social situation of mental patients and other inmates. Garden City, NY: Anchor Books.

Hansen, O., Monteiro, E., \& Hatling, M. (1996). Developing information infrastructure: The tension between standardization and flexibility. Science, Technology, \& Human Values, 21, 407-426. http://dx.doi.org/10.1177/016224399602100402

Law, J., \& Urry, J. (2004). Enacting the social. Economy and Society, 33, 390-410. http:// dx.doi.org/10.1080/0308514042000225716

Library and Archives Canada. (1861a). RG17, Census Field, district no. 3, Kitley Township, Leeds County.

Library and Archives Canada. (1861b). RG31, Census Field, Delaware, Middlesex County.

Lynch, M. (1991). Method: Measurement - Ordinary and scientific measurement as ethnomethodological phenomena. In G. Button (Ed.), Ethnomethodology and the buman sciences (pp. 77-108). Cambridge, England: Cambridge University Press.

Poovey, P. (1998). A history of the modern fact: Problems of knowledge in the sciences of wealth and society. Chicago, IL: University of Chicago Press. http://dx.doi.org/10.7208/ chicago/9780226675183.001.0001

Prentice, A. (1975). Education and the metaphor of the family: An Upper Canadian example. In M. Katz \& P. Mattingly (Eds.), Education and social change: Themes from Ontario's past (pp. 110-132). New York, NY: NYU Press.

Public Archives of Ontario. Record Group 2, Education, Incoming Correspondence, C-6-C; Outgoing Correspondence, C-2.

Sager, E. (1998). Employment contracts in merchant shipping: An argument for social science history. In F. Iacovetta \& W. Mitchinson (Eds.), On the case: Explorations in social bistory (pp. 49-64). Toronto, Canada: University of Toronto Press.

Scott, J. C. (1998). Seeing like a state: How certain schemes to improve the buman condition have failed. New Haven, CT: Yale University Press.

Szakolczai, A. (1998a). Max Weber and Michel Foucault: Parallel life works. London, England: Routledge.

Szakolczai, A. (1998b). Reflexive historical sociology. European Journal of Philosophy, 1, 209-227.

Szakolczai, A. (2000a). Norbert Elias and Franz Borkenau: Intertwined life-works. Theory Culture Society, 17, 45-69. http://dx.doi.org/10.1177/02632760022051103 
Szakolczai, A. (2000b). Reflexive historical sociology. London, England: Routledge.

Weir, L. (2006). Pregnancy, risk and biopolitics. On the threshold of the living subject. London, England: Routledge. 
